This item was submitted to Loughborough's Research Repository by the author.

Items in Figshare are protected by copyright, with all rights reserved, unless otherwise indicated.

\title{
Servitization: is a paradigm shift in the business model and service enterprise required?
}

PLEASE CITE THE PUBLISHED VERSION

http://dx.doi.org/10.1002/jsc.1929

PUBLISHER

(c) John Wiley \& Sons, Ltd.

VERSION

SMUR (Submitted Manuscript Under Review)

LICENCE

CC BY-NC-ND 4.0

REPOSITORY RECORD

Barnett, N., Glenn Parry, M. Saad, Linda B. Newnes, and Yee M. Goh. 2019. "Servitization: Is a Paradigm Shift in the Business Model and Service Enterprise Required?". figshare. https://hdl.handle.net/2134/12025. 
This item was submitted to Loughborough's Institutional Repository (https://dspace.lboro.ac.uk/) by the author and is made available under the following Creative Commons Licence conditions.

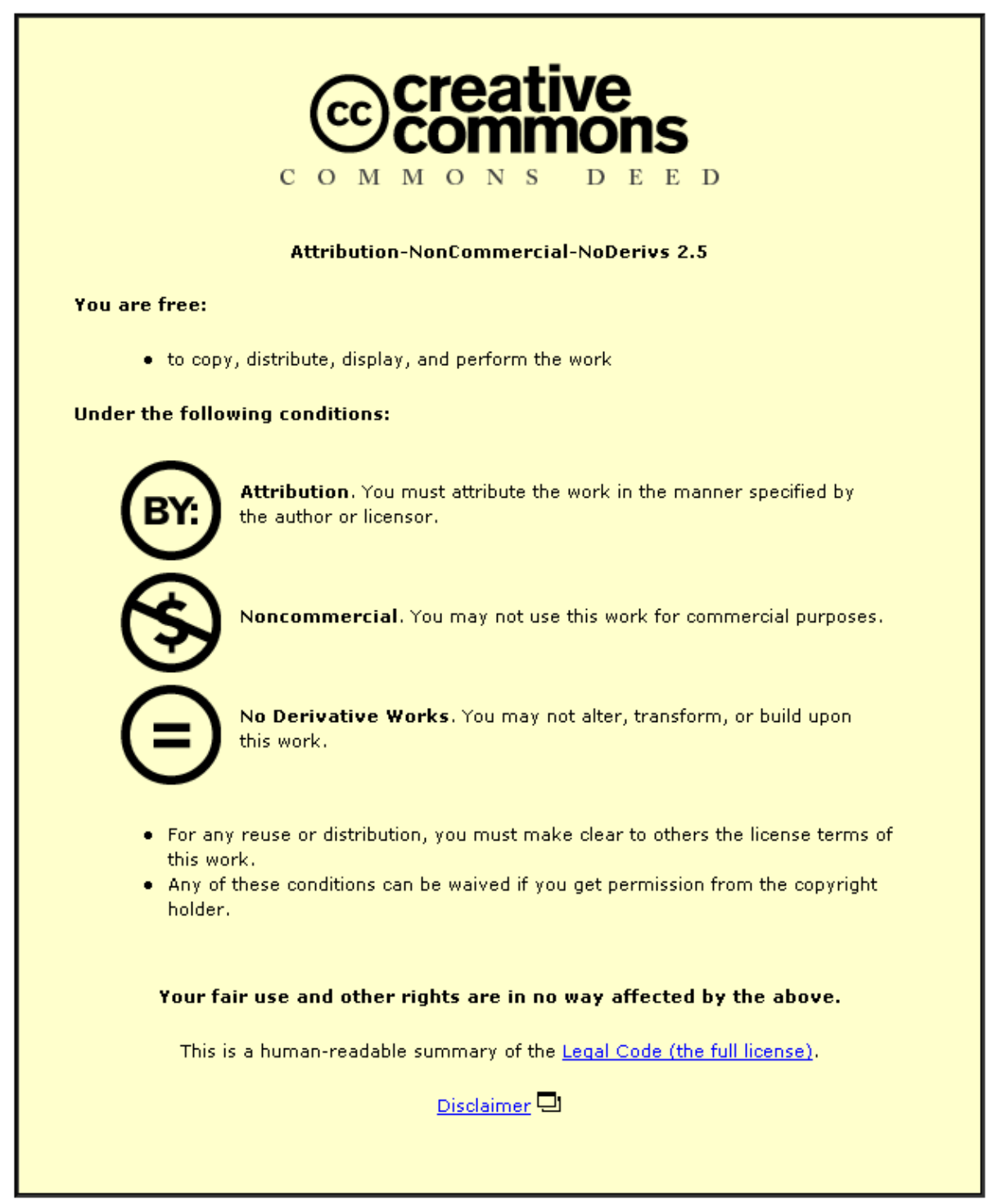

For the full text of this licence, please go to: http://creativecommons.org/licenses/by-nc-nd/2.5/ 
SERVITIZATION - COMPLEX ENGINEERING SERVICE AVAILABILITY- IS A PARADIGM

SHIFT IN THE BUSINESS MODEL AND SERVICE ENTERPRISE REQUIRED?

The research reveals the challenges of servitization and considers if incremental change is sufficient to deliver the anticipated benefits.

\author{
N. Barnett*, Dr. G. Parry*, Professor M. Saad*, Dr. L.B. Newnes \pm , Dr. Y. M. Goh^^ \\ *University West of England; \pm University of Bath; ^ Loughborough University
}

\title{
ABSTRACT/KEY POINTS
}

In many sectors customers are increasingly seeking service contracts rather than buying products. High tech capital equipment firms attracted by the potential revenue benefits are choosing to move from supplying product only to supplying product and services. The academic literature suggests that business will face challenges in undertaking the transformation from product to service provision and that organisational, cultural, commercial and operational problems have the potential to erode the potential benefits. A better understanding of service business dynamics is required. A case study of a complex engineering service was undertaken. Findings identified multiple challenges associated with the transformation from product to service provision that include strategy, organisation and enterprise management, contracting, risk, culture and operations. Considering these findings holistically it is suggested that a paradigm shift may need to occur, changing both managers perspective and the business models employed to provide service. 


\section{INTRODUCTION}

This research examines servitization, the move by manufacturing companies towards offering goods and services rather than goods alone (Neely 2008). This research considers whether the product value chain that developed and produced the original asset can efficiently provide a complex engineering service or whether a new business model is required (Ng et al., 2011). The transformation challenges are given specific focus, achieved through a detailed literature review and by case study analysis.

Refocusing substantial firm activity from producing output of primarily manufactured goods to providing goods and services can be likened to a revolution in business terms (Vandermerwe and Rada 1988). Servitization was described in the literature in terms of an activity undertaken by firms seeking to add value through service provision and subsequent research focused on the incremental changes required for firms to realize value by adding services to their product offering (Vandermerwe and Rada 1988). In this work, in contrast to this 'value add' approach, a contemporary view on services, and service dominant logic is applied which re-frames both product and service as 'service' where value is co-created between parties (Vargo \& Lusch 2007). This not only involves the provider firm changing the way it thinks and works but also drives change at the customer and through the supply base who all need to play a more proactive part throughout the product life cycle (Poirier 2004). The case study identifies the multitude of transformation challenges experienced by those working in a complex business engaged in a process of servitization (Oliva \& Kallenberg 2003; Baines et al., 2009). The research considers changes required from the perspective of all stakeholders. Strategy, organisation, enterprise management, contracting, culture and operations are all highlighted by the research as key areas for change. 


\section{LITERATURE REVIEW}

Vandermerwe and Rada (1988) consider servitization as a movement in which companies consciously develop service offerings which support their products to gain competitive advantage. By adding services to core products already supplied firms differentiate their offering from competitors, increasing customer dependency and establishing barriers to competition. This definition of servitization is presented in the context of 'value adding' where servitisation is discussed in terms of adding services to products to create new revenue streams (Vandermerwe and Rada 1988).

Multiple descriptors of the different types of 'value added' product service business can be identified in literature on Product Service Systems. Hockerts and Weaver (2002) establish three different forms of Product Service System: Integration oriented Product-Service System, includes the provision of both products plus services; Product oriented Product-Service System, reflecting product delivery plus directly related services; Product-Service System introducing services, which are incorporated into the product itself. Neely (2008) suggests two further categories reflecting integrated product and service offerings delivering value in use rather than value in exchange. These are use oriented Product Service Systems, where the service provider retains the ownership of the tangible product and result oriented Product Service Systems where the product is replaced with a service.

The language of 'adding value' reflects a goods dominant logic, where value is realized through exchanges in a market (Vargo and Lusch 2007). Business logics are not academic theories, but instead capture the practical linkages made by managers with regards to their mental representation of the world, as constructed from their experience, and their likely response to change (Kiesler and Spoul 1982). A dominant logic refers to the shared mental maps which groups of manager's use and develop as part of core business operations (Ng et al., 2012). Business in general has been developed around the dominant logic of tangible goods. The goods centered lexicon: 'product', 'production', 'goods, 'producer', 
'distribution' reflects more than just the words to talk about goods. It reflects an underlying paradigm for thinking about marketing and production as a system of value exchange (Vargo and Lusch 2007). Goods dominant logic becomes a problem for discussing a counter-paradigm.

Manufacturing firms are progressively moving towards offering services to avoid competing on cost alone and believe there are multiple opportunities to secure increased benefits and longevity (Vandermerwe and Rada 1988). Firms believe that increasing services will deliver higher margins (Gebauer et al., 2005) and that offering services as well as products increases the level of differentiation (Vandermerwe and Rada 1988). However financial returns have not been reported as expected, especially in the larger firms in highly developed economies that dominate the movement seeking higher profit (Neely 2008). Neely (2008) suggests that servitized firms generally have higher average labour costs, working capital and net assets than the pure manufacturing firms and appear unable to cover the additional costs and investment required for service provision and sufficiently increase revenues or gain extra margin. A cognitive phenomenon observed in 'product' managers limits the manager's motivation to extend to a service business. This erodes service quality and can develop into a self-fulfilling cycle of lower economic potential and increased risk that reduces the chance of achieving a successful transformation (Gebauer et al., 2005). The service business model changes from a focus on transactions to relationships and appears difficult and slow to implement in the larger and more complex organisations (Oliva and Kallenberg 2003). Developing new capabilities will necessarily divert financial and managerial resources away from the manufacturing and development of new products, the traditional sources of competitive advantage for the organisation (Oliva and Kallenberg 2003).

The literature provides different transformational frameworks for the firm as it moves from the unservitized to the servitized state. Oliva and Kallenberg (2003) propose a structured progressive step-bystep approach towards servitization with the provider taking the initiative. This includes identifying 
potential services to offer, progressively entering the service market of the installed product base, extending the firms offering to include servicing to service equipments supplied by others and finally taking over customer activity to deliver outcome. Alternatively a more adaptive responsive manner developing increasing levels of service and interaction with the customer can be taken. Here the customer and the supplier move towards servitization together (Martinez et al., 2010). Different constructs may be established for product and services delivery that may be delivered to the market separately. Understanding the differences in scope, value and operational characteristics required for product focus, product centered services and services focused operations is viewed as key as differing blends of transactional activities supported by a customer management function is required (Baines et al., 2009). Focused modular networked organisation complete with improved processes to manage resource, knowledge and qualified staff can also be employed to improve efficiency (Meier et al., 2011).

It is proposed that more significant change is required to deliver a complex engineering service where the outcome is emergent i.e. unknown or unpredictable at the outset. Such service may be delivered by a complex system of interacting business parties, transforming people information and materials and equipment simultaneously (Ng et al., 2011). Sharing of information and recognizing the shift in risk ownership (Pay \& Collins Bent 2008) and delivering transformation in a consistent, stable manner is identified as key to co-creating value in partnership with suppliers (Ng et al., 2011). Both culture and operations need to change when firms move towards service provision. Service characteristics including intangibility and customer contact require service employees to display more initiative, to cope more effectively with stresses placed upon them, to be more interpersonally flexible and sensitive and to be more co-operative than their colleagues who work in manufacturing (Schneider 1995). Ng et al., (2011) extend the above themes by proposing the customer and provider organisation, mind-set and culture needs to develop to include cooperative and communicative values reflecting a partnering culture, which 
encourages reward and communication. A win-win situation is then created by complimentary interdependence (Duffy \& Fearne 2004; Ng et al., 2011).

Service dominant logic provides a different perspective on business and helps guide action (Vargo and Lusch 2007). Service dominant logic introduces a shift from use of the plural term services, reflecting an intangible product to the singular term service that reflects the process of using ones resources for the benefit of another entity (Vargo and Lusch 2007). Vargo (2012) further refined service dominant logic describing the following guiding principles; service is the fundamental basis of exchange; the customer is always a co-creator of value; all economic and social actors are resource integrators; and value is always uniquely and phenomenological determined by the beneficiary. $\mathrm{Ng}$ et al., (2011) reflect the concepts introduced by service dominant logic by highlighting co-creation of value and the need for a dynamic system approach and introduce a new framework for complex service delivery. This framework shows that service is delivered by a complex system comprised of interacting parties simultaneously transforming people, information and materials and equipment in a consistent, stable manner. The term service enterprise is used to describe the complex system of interconnected and interdependent activities undertaken by a diverse network of stakeholders for the achievement of a common significant purpose (Purchase et al., 2011).

In summary literature on servitization is relatively new and the understanding of the phenomenon is developing quickly. Early literature introduces servitization as a 'value added' activity where services are added to supplement product already supplied (Vandermerwe \& Rada 1988). In support literature proposes that incremental changes are introduced to culture and operations to ensure delivery (Oliva \& Kallenberg 2003, Baines et al., 2009). More contempory literature on servitization however employs some of the concepts introduced by Service dominant logic (Vargo \& Lusch 2007) and focuses on service 
rather than product and services describing it as a dynamic activity where value emerges as a result of cocreation between customer, provider and suppliers (Ng et al., 2011).

\section{RESEARCH METHOD AND FINDINGS}

The research adopted a single case study approach as the focus is on a contempory phenomenon within a real life context where an in depth understanding is required. The interaction between a phenomenon and its context is a good opportunity to better comprehend complex issues (Weick 1979). For Easton (1995) a single case approach, which is very specific to a given situation, is very likely to produce a thorough and in-depth analysis of complex engineering service.

The approach was from the perspective of a constructivist reflecting the complexity of the research subject and that individuals view the world through their own framework. This allows for the understanding of both the factual side of the industrial activity and the different perceptions of the individuals within it. The research was qualitative taking the form of semi-structured interviews to gain understanding. The unit of analysis was the provider and key supplier of a complex engineering service where in depth interviews were undertaken with senior managers. Interviews focused on the features and challenges of servitization including value in use, co-creation, and supply-chain and enterprise management (Vargo and Lusch 2007; Ng et al., 2011; Purchase et al., 2011). The interviews were recorded and then transcribed and coded. This established six deductively derived categories of issues raised, Servitisation (raised 34 times); Skills (20); Customer and Value in use (29); Co-creation (15); Suppliers (16); Enterprise (15). A second set of categories inductively established from issues repeatedly raised by interviewees included: Culture and organisation (92); Contract (58); Performance (59); Cost (48); Equipment failures (33); Design (26). Analysis of data and comparison between individual interview findings and cross-functional and cross company synthesis was undertaken. All interviewees confirmed that transformation from offering and delivering a product to offering and delivering a service is difficult 
and slow. The transformation was considered especially difficult due to the complexity of service and size and interdependence of the organisations involved in the activity. Each interviewee understood the concept of servitisation, directly relating it to the availability contract between the provider and their end customer and recognised the effort his or her respective management and employees were making regarding this subject. At the provider, interviewees stated that their organisation was currently undergoing a significant transformation moving from product to both product and service provision. This was characterised as slow and difficult with one of the interviewee's suggesting that despite being three years into the process they were only now reaching critical mass in understanding the nature of the change.

"I think we are at the point where we have two equal camps. Half still in design and make world and thinks the job stops when it leaves the factory and then the other half of the business which is trying to get more recognition, more understanding and therefore more emphasis on changing behavior, process and culture we need to effectively build a service." Provider.

Significantly all interviewees repeatedly raised the same underlying issues: contracting (58 times); culture and organisation (92 times); performance (59 times); design and related equipment failures (59 times); and customer behavior (29 times). These concerns are captured in more detail below.

Contracting, organisation and culture were all raised as concerns and areas that need to be further addressed in order to progress with the transformation. All interviewees considered that existing contracting practices did not reflect the new service business model. Contracts were considered product rather than service oriented and did not sufficiently reflect the fact that the commercial and operational risk had now transferred from the operator to the provider. This was viewed as hindering the move to a more flexible responsive customer culture. The existing contracts were also thought to be too short in 
duration making it difficult to gain investment approvals against required design change, as pay back periods were too short. It was also felt that the contracts did not reflect the interdependence between stakeholders and did not include sufficient shared objectives required to drive optimal co-creation and continuous improvement of financial results. Furthermore interviewees believed their organisations are complex and remain functionally strong even though initiatives were in place to improve flow of activities across boundaries. The functional divisions and culture were viewed as stifling positive responsiveness to customer requests with the strength of the organizational functional divisions the reason for slow flow of product and activity up and down the supply chain. The co-creation of value was recognised by all the provider interviewees who felt significant numbers of their employees were working in teams with the customer, either under provider or customer lead. The supplier interviewees advised that their on-going interaction with the in service asset only needed one field representative. They added if they had control of more equipment they would place resource next to the asset that would provide efficiency gains due to expert knowledge being close at hand to reduce equipment returns. The discussion with the interviewees provided the understanding that the required culture and co-creation existed with immediacy of action in front office locations where customer and provider staff worked together. When the activity moved to the back office across the greater organisation there was a lesser appreciation of cocreation and willingness to be responsive.

Enterprise management, supplier and performance management were all discussed. The provider interviewees believed the availability and support activity were well managed by a dual headed (provider and customer) project team. However they confirmed that real boundary crossing management did not exist. Sharing of objectives was also unclear. The supplier interviewees had limited visibility of the combined provider customer management and suggested improved communication and common objectives would be of benefit. 
"Its difficult and maybe too big to manage and I think the way to do it is to have a virtual enterprise and make sure that people in it all have the same objectives from the top to the bottom. It should all be about (operation of the product)" Supplier.

All interviewees were aware of performance measures cascading from the key performance indicators of the main deliverable. They advised that measures cascade down and roll up through the organisation and the greater supply chain (Nudurupati 2011). Tangible and intangible measures exist including measures on the customer. The provider advised that they agree similar general terms and conditions to their suppliers together with specific statements of work that capture the actual level of service they are seeking on specific equipment. The provider's procurement team measure supplier's performance and Key Performance Indicators get consolidated to the product level. Poor performance is discussed with the suppliers and any additional costs are minimized and/or absorbed by suppliers. However not every cost associated with disruption and extra effort through the supply chain are captured or recovered. Some availability contracting has been introduced and some suppliers are working either with provider or independently towards reducing equipment failures. The supplier interviewees recognised that a number of tangible and intangible key performance indicators and specific turnaround times had been flowed down to them from the Provider but did not recognise contract changes reflecting the shift in risk ownership.

Design and equipment failures appeared at the centre of many operational problems. All interviewees believed that the equipment designs were under optimized for through life availability reflecting that they were established for product exchange rather than value in use. The equipment designs are old and redesign difficult to achieve due to the short term contracting, cost of redesign and qualification and the risk averse culture of the organisation. Equipment failures continue at a high rate driven by product design and customer use. This is a concern for the provider as they are now carrying the risk. Assets 
requiring repair also move slowly through the extended supply chain. The supplier interviewees advised that they were subject to manageable turnaround times on repairs. However they regularly receive batches of equipments that demand increased flexibility in their work areas. Whilst their processes are capable, large batches of parts for repair can overwhelm these areas. This creates extra cost as management add shifts, reallocates resource and move test equipment to meet spikes in demand.

Value in use was understood by all and gave rise to many comments on customer created problems. First the end customer is considered a dynamic organisation that required the product back in service as soon as possible following failure. This could lead to incorrect identification of problems in an attempt to speed the repair process. Technicians may replace component parts that were functioning, which gave rise to no fault founds entering the returns system. As the actual cause may not be identified in a timely manner epidemics of equipment failures could sometimes arise. Second all believed customer damage to equipment during operations existed and was the cause of further repair activity and spares provision. Changing the actions of the customer users could reduce these failures.

\section{DISCUSSION}

The case study organisations do not appear to have adopted a holistic strategic approach to service implementation but have responded to a difficult business situation and directly moved to providing availability contracting by utilising their existing organisation. This is different from the progressive transfer to the servitized state proposed by Oliva and Kallenberg (2003) and also differs from the adaptive approach proposed by Martinez et al., (2010), which has potentially exacerbated what is a difficult transformation. Incremental changes to culture and operations have been established however the whole enterprise has yet to understand the fundamental differences between goods dominant logic and service dominant logic (Vargo and Lusch 2007) and the need to move to a new dynamic service system way of 
working (Ng et al., 2011). The enterprise has established a project group to manage the availability of the equipment with dual leadership, split between the provider and the customer. This joint leadership approach is one step towards more effectively working together to co-create value and is considered positive for the management of the immediate interface and tangible to the front office (Pay and Collins Bent 2008). However the joint leadership and common purpose appears less obvious and is physically remote to the back office or greater organisation engaged in supporting the service activities and falls short of the service enterprise management (Purchase et al., 2011). Transformation to the servitized state was described as difficult by managers reflecting the 'paradox issues' (Neely 2008). The risk averse product culture remained strong and is maintained by the existing risk averse contracting practices (Kim et al., 2007) and functional and firm silos remain unchanged throughout the supply chain impacting flexibility and speed of response. Designs of equipment are considered suboptimal for service contract provision, however they are difficult to change due to the high cost and short contracts as well as the fundamental issues highlighted above. Interdependence between the partners who are required to deliver the service creates a need to work and function as one business. It is the ability to co-ordinate resources from multiple sources effectively which creates value propositions that directly create advantage in the market (Ng et al., 2011). However the project management and performance measurement introduced does not appear sufficient to overcome the cultural and organisational barriers. Traditional value chains with handover points may suit value exchange businesses but complex service needs to be delivered by organisations that simultaneously work together to create value (Ng et al., 2011).

Based on the research findings, where availability of a complex engineering service is required incremental changes to the existing way of working (Oliva and Kallenberg 2003) would not appear to be a sufficient approach to such a transformation. A more fundamental shift is needed to address the challenges of servitization. Functionally structured firms within a value chain acting sequentially and which is bound by a risk averse contracting appear incompatible with the demands of a dynamic complex 
engineering service, (Vargo and Lusch 2007; Ng et al., 2011). The evidence of poor returns identified by Neely (2008) demonstrates the need for a paradigm change. This paper therefore proposes that a paradigm shift in the way of working including a focused service organisation is considered, a step further than the networked organisation structure proposed by Meier et al., (2011). An organisational shift away from the value chain should to be established in conjunction with new ways of working and increased customer focused culture. The new arrangements will need to reflect interdependencies beyond firm boundaries providing an enterprise perspective, which addresses all of the challenges collectively (Purchase et al., 2011). From an operational perspective a dynamic service enterprise comprising of the customer, provider and suppliers based on close internal relationships will potentially overcome many of the problems identified in the research helping avoid the service paradox (Neely 2008). One recognised leader, one business direction and one set of common objectives across all boundaries would increase the focus towards service (Pay and Collins Bent 2008). The multi-organisational service enterprise will collectively work towards the same targets and collectively hold and manage the commercial and operational risk rather than contractually hand it off to one another, as is currently the case (Purchase et al., 2011; Pay and Collins Bent 2008). The provider and supplier need to become more output focused (Baines et al., 2009) and the customer needs to become part of a team, a requirement to efficiently co-create value (Ng et al., 2011). The service enterprise should be established and supported by the product organisation rather than being a product organisation with an extended service activity. Current suppliers as part of the new service enterprise are directly involved in co-creating value and bring their technical expertise to bear immediately upon service provision avoiding equipment failures, repairs and no fault founds in the system.

Table 1. Link between issues identified in the literature review and the case study with proposal elements and new potential outcomes. Whilst the table identifies issues separately in reality these issues are linked. 


\section{CONCLUSION}

This paper reviews the development of servitization and includes the perceived benefits expected and associated challenges as a result of such a transformation (Vandermerwe and Rada 1988; Neely 2008). This is supported by a case study of a hi-tech capital equipment service enterprise providing complex engineering service system availability. The case study confirms the difficulties of transformation found in literature (Oliva and Kallenberg 2003) highlighting multiple organisational, cultural and operational challenges that need to be managed and overcome to deliver optimal returns (Neely 2008). The findings of the case study additionally highlight concerns over the design of equipment and customer management, which together with the problems associated with rigid contractual management and extended value chains are believed to give rise to equipment failures and inefficient operations respectively. Mixing different business models and delivery constructs across multiple complex organisations (Baines et al., 2009) appears difficult to achieve, as each construct demands very different management dynamics. This also perpetuates the notion of product and services as opposed to service (Vargo \& Lusch 2007).

Reviewing the research findings collectively, and building on and supporting extant literature (Ng et al., 2011; Meier et al., 2011) and employing service dominant logic (Vargo and Lusch 2007) to understand the dynamics of servitization, the paper proposes that incremental changes in management and operations need to be replaced by a paradigm shift in ways of working to achieve servitization. The proposal highlights that any future arrangement should consider establishing a single dynamic enterprise that has the prime shared objective of providing the required service. The enterprise should be as autonomous as possible and organised for efficiency with a strong outcome focused culture (Baines et al., 2009). Commercial frameworks should reflect the fact that the commercial and operational risk is now shared across the enterprise (Pay and Collins Bent 2008). This will encourage flexibility and speed of response 
and problem resolution. The new arrangement will address the challenges of servitization collectively facilitating the delivery of an efficient service.

This research extends literature by providing evidence that incremental changes are insufficient when considering complex engineering service availability contracting (Ng et al., 2011). The research is based on an in-depth single enterprise case study in the aerospace domain in the context of high-tech capital equipment service availability. Generalisability may be possible within aerospace where complex engineering service is being provided. Further research is planned to develop the nature of the required organizational transformation to implement this paradigm shift.

\section{REFERENCES}

Araujo, L, \& Spring, M, 2006, Services, products and the institutional structure of production, Industrial Marketing Management, vol.35, no. 7, pp. 797-805.

Baines, T, Lightfoot, H, Peppard, J, Johnson, M, Tiwari, A, Shehab, E. \& Swink, M, 2009, 'Towards an operations strategy for product centric servitization’, International Journal of Operations and Production management, vol. 29, no.5, pp. 494-519.

Bowen, J, \& Ford, R, C, 2002, 'Managing Service Organisations: Does having a thing make a difference' Journal of Management, vol. 28, no.3, pp. 447-469.

Brandt, J, 2008, Beyond the supply chain, Industry week, vol. 247, no. 20, pp. 6.

Butterfield, J, Ng, I, Roy, R, McEwan, W, 2009, Enabling value co-production in the provision of support service engineering solutions using digital manufacturing methods, Winter simulation conference Austin, Texas, USA.

Coleman, J, S, Social Capital in the creation of human capital, American journal of sociology, vol.94, supplement, pp. 95-120. 
Davies, A, Brady, T, \& Hobday, M, 2006, ‘Charting a path towards integrated solutions’, Sloan Management Review, spring, pp. 38-49.

Duffy, R, \& Fearne, A, 2004, 'The impact of Supply chain partnership on supplier performance', The international journal of logistics management, vol.15, no 1, pp. 57-71.

Easton, G, 1995, Case research as a methodology for industrial networks: a realist apologia. Proceedings from the $11^{\text {th }}$ IMP Conference, Manchester. Manchester Federal School of Business and Management, pp368-91.

Edvardsson, B, Gustafsson, A \& Roos, I, 2005, 'Service portraits in service research: a critical review', International Journal of Service industry Management, vol. 16, no.1, pp. 107-121.

Gebauer, H, Fleisch, E, \& Friedli, T, 2005, 'Overcoming the service paradox in manufacturing companies', European Management Journal, vol. 23, no. 1, pp. 14-26.

Grant, R, M, 1996, Toward a knowledge based theory of the firm, strategic management journal, vol.17, winter special, pp. 109-122.

Johnstone, S, Dainty, A \& Wilkinson, A, 2008, 'In Search of product service: evidence from aerospace, construction and engineering', The Service Industries Journal, vol.28, no. 6, pp. 861-875.

Kerr, C, I, V, Phaal, R, Probert, D, R, 2008, Technology insertion in the Defence industry, A, primer, Proceedings of the institution of Mechanical Engineers, part B, Journal of engineering manufacturing vol. 222, no. 8, pp. 1009-1023.

Kiesler, S, \& Sproul, L, 1982, Managerial response to changing environments, Perspectives and problem sensing from social cognition, Adm. science quarterly, vol. 27, no.4, pp. 548-570.

Kim, S, Morris, A, Cohen, M, \& Netessine, S, 2007, Performance contracting in after sales service supply chains, Management Science, vol. 53, no. 12, pp. 1843-1858.

Macintyre, M, Parry, G, \& Angelis, J, 2011, Service Design and Delivery, New York, Springer.

Martinez, V, Bastl, M, Kingston, J, \& Evans, S, 2010, 'Challenges in transforming manufacturing organisations into product-service providers’, Journal of Manufacturing Technology Management, 
vol. 21, no.4, pp. 449-469.

Meier, H, Volker, O \& Funke, B, 2011, Industrial Product-Service Systems (IPS²), Paradigm shift by mutually determined products and services, International Journal of Advanced Manufacturing Technology, vol.52, pp. 1175-1191.

Mills, J., Crute, V, \& G.Parry, 2009, Value co-creation in a UK Air Defence, service availability contract - the problem of multiple customer perspectives and diverse cultures, The European Inst. for Advance Studies in Management, Naples Forum on Services: Service-Dominant Logic, Service Science and Network Theory, Capri.

Neely, A, 2008, 'Exploring the financial consequences of the servitization of manufacturing', Operations Management Research, vol. 1, no. 2, pp. 103-118.

Ng, I, C, L, Maull, R \& Yip, N, 2009, 'Outcome based contracts as a driver for systems thinking and Service dominant logic in service science: evidence from the defense industry', European Management Journal, vol. 27, no. 6, pp. 377-387.

Ng, I, Parry, G, Wild, P, McFarlane, D, \& Tasker, P, 2011, Complex Engineering Service Systems: Concepts and Research, London Springer.

Nightingale, P, 2000, The product-process-organisation relationship in complex development projects, Research Policy, Elsevier, vol. 29(7/8), pp. 913-930, August.

Oliva, R, \& Kallenberg, K, 2003, 'Managing the transition from products to services', International Journal of Service Industry Management, vol. 14, no. 2, pp. 160-172.

Osterwalder, A \& Pigneur, Y, 2010, Business Model Generation, Hoboken, New Jersey, John Wiley \& Sons, Inc.

Parassuraman, A, \& Zeithaml, V, A, \& Berry, L, L, 1985, 'A conceptual model of service quality and its implications for future research’ Journal of Marketing, vol. 49, pp. 41-50.

Parry, G, Newnes, N, \& Huang, X, 2011, Goods, Products and Services, Service Design and Delivery, ed. Macintire, Parry, Angelis, London, Springer. 
Pay, G, \& Collins-Bent, N, 2008, A partnered approach to contracting for availability - Lessons learned by MOD/AgustaWestland on IMOS \& SKIOS, Presentation, Contracting for availability and capability symposium, Shrivenham, June 17-18.

Poirier, C, C, 2004, 'Using models to improve the supply chain', New York, St Lucie Press.

Prahalad, C, K, \& Ramasway, V, 2003, The New Frontier of Experience Innovation, MIT, Sloan management review, vol.44, no.4, pp. 12-18.

Prahalad, C, K, \& Ramasway, V, 2004, ‘Co-creation of Experience: The next practice in value creation’, Journal of Interactive Marketing, summer vol. 18, no.3, pp. 5-14.

Purchase, V, Parry, G, Valerdi, R, Nightingale, D, \& Mills, J, 2011, Enterprise Transformation: Why are we interested, what is it, and what are the challenges, Journal of Enterprise Transformation, vol.1, no.1, pp. 14-33.

Schneider, B, 1995, Winning the service game, Boston, Harvard business school press.

Shank, J, K, \& Govindarajan, V, 1992, Strategic cost management: The value chain perspective. Journal of Management Accounting Research, Winter, pp. 179-197.

Spring, M, \& Araujo, L, 2009, Service, services and products: rethinking operations strategy, International Journal of Operations \&Production Management, vol.29, no.5, pp. 444-467.

Thomas, D, R, E, 1978, Strategy is different in service businesses, Harvard Business Review, vol.56, no. 4, pp. 158-165.

Ulega, W, 2001, Customer value in business markets an agenda for inquiry. Industrial Marketing Management, vol. 30, no. 5, pp. 315-319.

Vandermerwe, S, \& Rada, J, 1988, 'Servitization of Business: Adding Value by Adding Services', European Management Journal, vol. 6, no. 4, pp. 314-324.

Vargo, S, L, \& Lusch, R, F, 2007, 'From goods to service(s): Divergences and convergences of logics’, Industrial Marketing Management, vol. 37, May, pp. 254-259.

Vargo, S, 2012, RMIT Foundation International visiting fellow presentation, Karslad University, 
Melbourne, Australia.

Voss, C, Roth, A, \& Chase, R, 2006, Experience, destination, services and service strategy, Working paper, Marshall school of business, University of Southern California, Los Angeles

Weick, K, E, 1979, The social psychology of organising, $2^{\text {nd }}$, New York, Random House.

Widen-Wuff, G. \& Ginman, M., Explaining knowledge sharing in organizations through the dimensions of social capital, Journal of Information Science, vol.30, no. 5, pp. 448- 458.

Wilkinson, A, Dainty, A, \& Neely, A, 2010, 'Changing times and changing timescales: the servitization of manufacturing’, Guest editorial from: International Journal of Operations and Production Management, vol. 29, no. 5, pp. 425-430.

Zeithamel, V, A, Parassurman, A, \& Berry, L,L, 1985, 'Problems and Strategies in Services Marketing', Journal of Marketing, vol. 49, spring, pp. 33-46. 


\section{TABLES}

Table1. Servitization issues and proposal(s).

\begin{tabular}{|c|c|c|c|}
\hline $\begin{array}{l}\text { Issues identified during literature } \\
\text { review and case study }\end{array}$ & Outcome & Proposal(s) & $\begin{array}{l}\text { Anticipated } \\
\text { outcome }\end{array}$ \\
\hline $\begin{array}{l}\text { Extended product value chain, (Porter } \\
\text { 1985). }\end{array}$ & \multirow[t]{4}{*}{$\begin{array}{l}\text { Poor service } \\
\text { performance }\end{array}$} & $\begin{array}{l}\text { Single dynamic value co-creating enterprise, (Ulaga } \\
\text { 2001; Prahalad and Ramasway 2003; Oliva and } \\
\text { Kallenberg 2003; Poirier 2004; Edvardson et al., 2005; } \\
\text { Spring and Araujo 2009; Mills et al., 2009; Ng et al., } \\
\text { 2009; Butterfied et al., 2009; Ng et al., 2011; Purchase et } \\
\text { al., 2011). }\end{array}$ & \multirow[t]{4}{*}{$\begin{array}{l}\text { Improved } \\
\text { service } \\
\text { performance }\end{array}$} \\
\hline $\begin{array}{l}\text { Functional and company silos, (Duffy } \\
\text { and Fearne 2004; Wilkinson et al., } \\
\text { 2010). }\end{array}$ & & $\begin{array}{l}\text { Reduced silos, (Grant 1996; Coleman 1998; Poirier } \\
\text { 2004; Duffy and Fearne 2004). }\end{array}$ & \\
\hline $\begin{array}{l}\text { Product based culture (Levitt } \\
\text { 1972,1976; Vargo and Morgan 2005). }\end{array}$ & & $\begin{array}{l}\text { Service based culture (Poirier 2004; Duffy and Fearne } \\
\text { 2004; Davis et al., 2006; Johnstone et al., 2008; Martinez } \\
\text { et al., 2010). }\end{array}$ & \\
\hline $\begin{array}{l}\text { Risk averse culture, (Gebaur et al., } \\
\text { 2005; Kim et al., 2007). }\end{array}$ & & $\begin{array}{l}\text { Shared risk/flexible culture (Parasuraman 1985; Bowen } \\
\text { and Ford 2002; Poirier 2004; Kim et al., 2007; Neely } \\
\text { 2008). }\end{array}$ & \\
\hline Customer risk not fully managed & \multirow[t]{3}{*}{$\begin{array}{l}\text { High } \\
\text { equipment } \\
\text { failures }\end{array}$} & $\begin{array}{l}\text { Improved customer management and improved customer } \\
\text { understanding (Duffy and Fearne 2004; Prahalad and } \\
\text { Ramasway 2004; Widen-Wuff and Ginman 2004). }\end{array}$ & \multirow{3}{*}{$\begin{array}{l}\text { Reduced } \\
\text { number of } \\
\text { equipment } \\
\text { failures in } \\
\text { service. }\end{array}$} \\
\hline $\begin{array}{l}\text { Product designed for product features, } \\
\text { (Zeithaml et al., 1985; Sasser et al., } \\
\text { 1978; Kerr et al., 2008). }\end{array}$ & & $\begin{array}{l}\text { Product designed for service, (Thomas 1978; Zeithaml et } \\
\text { al., 1985; Shank and Govindarajan 1992; Araujo and } \\
\text { Spring 2006; Ng et al., 2009; Baines et al., 2009; } \\
\text { Macintyre et al., 2011). }\end{array}$ & \\
\hline $\begin{array}{l}\text { Difficult and long design change } \\
\text { process and rigid short term } \\
\text { contracting. }\end{array}$ & & $\begin{array}{l}\text { Shortened/ dynamic design change process and more } \\
\text { flexible contracting and longer term contracting, (Voss et } \\
\text { al., 2006; Pay-Collins Bent 2008; Kerr et al., 2008; } \\
\text { Butterfied et al., 2009; Ng et al., 2011). }\end{array}$ & \\
\hline Limited enterprise management & $\begin{array}{l}\text { Multiple } \\
\text { organisational } \\
\text { direction and } \\
\text { objectives, } \\
\text { (diluted } \\
\text { effort). }\end{array}$ & $\begin{array}{l}\text { Service enterprise management with single set of } \\
\text { enterprise objectives (Brandt 1998; Nightingale 2000; } \\
\text { Ulaga 2001; Pay-Collins Bent 2008; Mills et al., 2009; } \\
\text { Wilkinson et al., 2010; Ng, Parry, McFarlane, Wild, and } \\
\text { Tasker 2011; Purchase et al., 2011;). }\end{array}$ & $\begin{array}{l}\text { Clarity of } \\
\text { direction and } \\
\text { objectives } \\
\text { and } \\
\text { improved } \\
\text { performance } \\
\text { for service } \\
\text { enterprise. }\end{array}$ \\
\hline
\end{tabular}


Corresponding author NJBarnett, University West of England Bristol, neil2.barnett@live.uwe.ac.uk, mobile.07588802324), 